\title{
Pelatihan Pendampingan Pembuatan Media Pembelajaran Interaktif dengan Memanfaatkan Aplikasi Zoom Meeting Basic Berbasis Multimedia Pada Guru YP TK Farhan An-Nur Batang Kuis-Deli Serdang
}

\author{
Suhendra1, Salam Irianto Nadeak ${ }^{2, *}$, Komda Saharja ${ }^{2}$ \\ 1 Program Studi Desain Grafis, Politeknik Negeri Media Kreatif, Medan, Indonesia \\ 2 Program Studi Teknik Grafika, Politeknik Negeri Media Kreatif, Medan, Indonesia \\ Email: 2,*salamirianto66@gmail.com
}

\begin{abstract}
Abstrak-Masa Pandemi Covid-19, semua tingkatan pendidikan yang dimulai dari TK hingga Perguruan tinggi mulai menggunakan media pembelajaran berbasis Multimedia, hal ini dikarenakan tidak terlaksananya pembelajaran secara tatap muka disemua kalangan tingkat pendidikan. Mitra Pengabdian kepada Masyarakat Kompetitif ini adalah kelompok guru Yayasan Pendidikan Islam TK Farhan An-Nur yang berlokasi di Jl. Peringgan Dusun III, Desa Tumpatan Nibung, Kec.Batang Kuis, Kab.Deli Serdang. Kelompok Bermain (KOBER) ini memiliki Guru 5 Orang dan 52 Orang Siswa. Selama Pandemi, sekolah menjalankan kegiatan Belajar Mengajar secara tatap muka dan bergantian, hal ini dikarenakan Permasalahan yang dihadapi mitra adalah para-Guru tidak mempunyai kemampuan dalam membuat dan merancang media pembelajaran interaktif berbasis multimedia dengan memanfaatkan conference apps antara lain zoom meeting basic. Namun demikian, kualitas belajar siswa tetap menurun karena durasi belajar yang pendek. Solusi yang ditawarkan adalah memberikan pelatihan merancang bahan ajar, memberikan pelatihan membuat video pembelajaran dengan memanfaatkan aplikasi yang saat ini sering digunakan pada guru dalam melakukan pembelajaran secara daring, yaitu zoom meeting basic. Metode dilaksanakan dengan cara ceramah dan praktik, dengan tiap jenis pelatihan dilakukan 4x2 jam pertemuan selama 1 bulan. Monitoring dan post kegiatan pelaksanaan pengabdian kepada masyarakat kompetitif dilaksanakan 2x yaitu bulan ke-1 dan bulan ke-4 setelah program selesai dilaksanakan untuk memastikan adanya keberlanjutan dari program yang telah dilaksanakan.
\end{abstract}

Kata Kunci: Media Pembelajaran Interaktif; Multimedia, Zoom Meeting Basic; Teknologi Informasi

\begin{abstract}
During the Covid-19 Pandemic, all levels of education starting from kindergarten to university began to use multimedia-based learning media, this was due to the lack of face-to-face learning at all levels of education. This Competitive Community Service Partner is a group of teachers from the Farhan An-Nur Kindergarten Islamic Education Foundation which is located on Jl. Peringgan Hamlet III, Tumpatan Nibung Village, Batang Kuis Subdistrict, Deli Serdang Regency. This Playgroup (KOBER) has 5 teachers and 52 students. During the Pandemic, schools run teaching and learning activities face to face and alternately, this is because the problem faced by partners is that teachers do not have the ability to create and design interactive multimedia-based learning media by utilizing conference apps, including basic zoom meetings. However, the quality of student learning continues to decline due to the short duration of study. The solutions offered are providing training in designing teaching materials, providing training in making learning videos by utilizing applications that are currently often used by teachers in conducting online learning, namely zoom meeting basic. The method is carried out by means of lectures and practices, with each type of training carried out $4 \times 2$ hours of meetings for 1 month. Monitoring and post implementation of competitive community service activities are carried out twice, namely the 1 st month and 4th month after the program is completed to ensure the sustainability of the program that has been implemented.
\end{abstract}

Keywords: Interactive Learning Media; Multimedia; Zoom Meeting Basic; Information Technology

\section{PENDAHULUAN}

Media Pembelajaran berbasis IPTEK maupun Multimedia saat ini sangat disenangi oleh semua kalangan mulai dari tingkatan pendidikan dasar hingga pendidikan tinggi. Karena selain menarik untuk dilihat dan dipahami hal tersebut juga akan menumbuhkan suasana yang menyenangkan bagi siapapun yang melihatnya. Gambar dan suara yang tampil juga membuat orang yang melihat tidak cepat bosan dan mudah dipahami. Selain dari itu setiap orang yang melihat media pembelajaran bisa lebih tekun dalam mempelajari materi melalui media pembelajaran berbasis multimedia, dikarenakan media ini dapat dilihat berulang-ulang hingga memahami materinya. Pada akhir tahun 2019 dunia dilanda dengan kemunculan virus Corona yang menyebabkan kondisi Pandemi, hal ini yang sekarang sering dikenal dengan Pandemi Covid-19. Indonesia merasakan dampak Covid-19 ini pada Maret 2020, disaat itu pula seluruh kegiatan di Indonesia mulai terhenti, termasuk kegiatan pendidikan. Pemerintah mengeluarkan Surat Edaran SE Nomor 4 Tahun 2020 melalui Menteri Pendidikan dan kebudayaan tentang Kebijakan Pelaksanaan Pendidikan pada Masa Darurat Covid-19, yang membuat seluruh kegiatan di kalangan pendidikan harus dilakukan secara daring dan menjalankan secara ketat protokol kesehatan. Hal ini yang membuat setiap institusi pendidikan dituntut untuk memberikan hingga menciptakan inovasi terbaru untuk proses pembelajaran yang efektif.

Saat ini pembelajaran secara daring sudah mulai diberikan kelonggaran, perlahan-lahan pemerintah sudah mulai memberi izin secara bertahap untuk melakukan pembelajaran secara tatap muka dengan tetap mematuhi protokol kesehatan secara ketat dan kuota peserta pendidikan yang dibatasi 50\% dari jumlah biasanya. Walaupun 
demikian tetap saja proses pembelajaran secara efektif, kreatif dan inovatif harus dihasilkan oleh tenaga pendidik agar dapat menghasilkan siswa yang kritis, kreatif dan kompeten. Berdasarkan hal ini guru te tap harus siap sedia dalam menyediakan media pembelajaran interaktif dan kreatif sehingga dapat digunakan secara daring maupun luring (tatap muka). Solusinya guru diharuskan untuk merancang media pembelajaran sebagai bentuk inovasi dengan memanfaatkan aplikasi Zoom Cloud Meeting atau lebih seringnya disebut zoom meeting. Berdasarkan informasi yang dikumpulkan pada pra pengabdian menunjukkan bahwa hanya 2 dari 5 orang guru yang mampu menggunakan teknologi dalam pembelajaran di Kecamatan Batang Kuis Deli Serdang. Pada masa kini pendidikan tidak dapat dipisahkan dari peran media pembelajaran dalam proses belajar dan mengajar (Tafano, 2018). Media pembelajaran berperan sebagai pengirim pesan kepada peserta didik sehingga dapat merangsang pikiran, perhatian serta minat untuk belajar. Membangkitkan keinginan belajar, memperjelas penyajian materi hingga kemampuan dalam menampilkan objek dalam pembelajaran merupakan peran media belajar untuk membuat peserta didik menangkap pelajaran dengan baik (Putra, 2015).

\section{METODE PELAKSANAAN}

Kegiatan ini dilaksanakan dengan menggunakan metode action research yang terdiri dari 4 (empat) tahapan yaitu: persiapan, tindakan, pendampingan dan post kegiatan. Dapat dilihat pada detail sebagai berikut ini.

\subsection{Persiapan}

Persiapan meliputi:

a. Persiapan administrasi, dimulai dari penyusunan program pelatihan dan pendampingan, pelaksanaan ini sebagai persyaratan bagi mitra dengan bersedia hadir saat pelatihan dimulai hingga selesai.

b. Persiapan waktu

1. Program Pengabdian kepada Masyarakat ini berlangsung selama 6 Bulan yang dilakukan setiap hari Jumat dan Sabtu.

2. 1 Jenis Pelatihan akan dijalankan selama 1 bulan dengan jumlah tatap muka sebanyak $4 \mathrm{x}$

3. 1 pertemuan berlangsung selama 2 jam

c. Persiapan Pengetahuan dan Keterampilan

1. Pelatihan desain bahan ajar yang menarik akan dibawakan oleh Ketua Pelaksana (Suhendra, ST., M.Kom)

2. Pelatihan membuat video ajar akan dibawakan oleh anggota pengusul 2 dan 3 (Drs. H. Salam Irianto Nadeak, M. Pd dan Komda Saharja, S.Kom., M.Pd )

3. Mengundang Narasumber Media Pembelajaran dari luar (Rizaldy Khair, S.Kom., M.Kom.)

d. Persiapan Sarana dan Prasarana

1. Ketua dan Anggota I menyediakan slide power point

2. Anggota II menyediakan video pelaksanaan

3. Mahasiswa akan menyediakan/menggandakan modul

4. Bahan dan peralatan akan disediakan oleh tim pengusul

Tindakan dan Pendampingan meliputi :

Metode Pelaksanaan Pelatihan Desain Bahan Ajar

Terdapat beberapa langkah yang dilakukan untuk pelatihan bahan ajar yaitu :

a. Dilakukan sosialisasi/pemahaman tentang bahan ajar serta materi ajar yang dilakukan 5 hari sebelum pelaksanaan pelatihan, dengan mengundang narasumber dari luar (Rizaldy Khair, S.Kom., M.Kom.)

b. Dilakukan pelatihan desain bahan ajar dengan metode ceramah dan praktek sebanyak 8x pertemuan

c. Pada pertemuan I: pengenalan aplikasi zoom meeting basic dan cara menggunakannya.

d. Pertemuan II : merekam video online menjadi video pembelajaran dengan zoom meeting basic.

e. Pertemuan III - IV : membuat konten bahan ajar

\section{Metode Pelaksanaan Pelatihan Pembuatan Video Ajar}

Terdapat beberapa langkah yang dilakukan untuk pelatihan yaitu :

a. Dilakukan sosialisasi/pemahaman tentang jenis - jenis video ajar yang dilakukan 2 hari sebelum pelaksanaan pelatihan

b. Dilakukan pelatihan membuat video ajar, dilakukan dengan cara ceramah dan praktek sebanyak 8x pertemuan

c. Pada pertemuan I : pengenalan video dan praktek membuat video menggunakan 2 aplikasi. Selanjutnya memberikan tugas demo setiap peserta.

d. Pertemuan II : pengenalan filmora dan praktek penggunaan filmora.

e. Pertemuan III - IV : praktek video ajar 


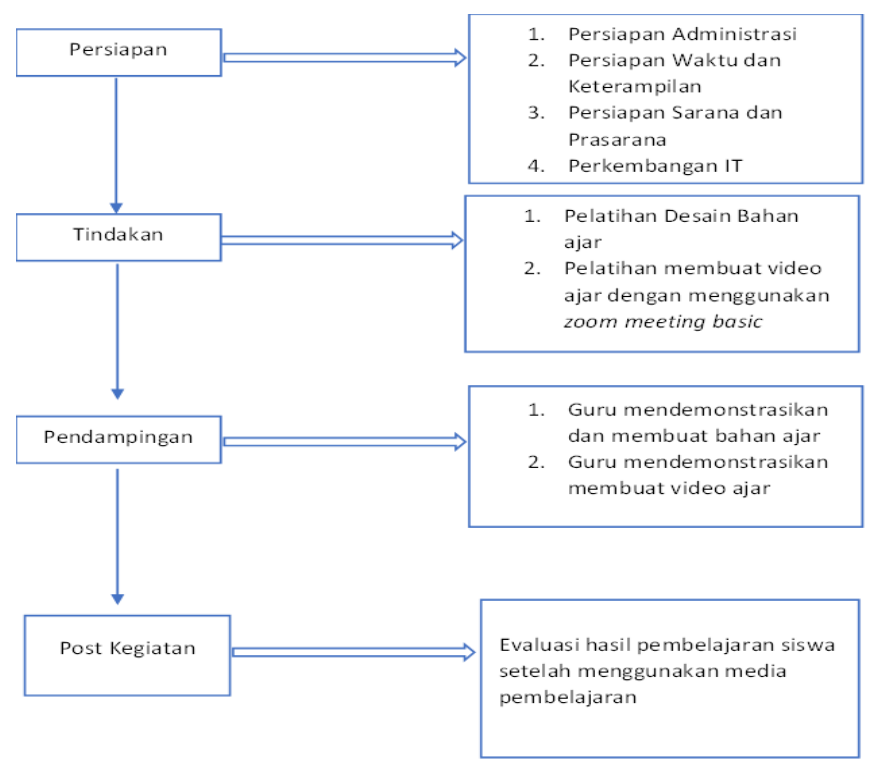

Gambar 1. Tahapan Pelaksanaan Kegiatan

\section{HASIL DAN PEMBAHASAN}

Kegiatan Pelatihan Pembuatan Media Pembelajaran Interaktif pertama kali dilakukan dengan memberikan materi pemahaman tentang jenis-jenis media pembelajaran dan bahan ajar serta materi ajar yang dilakukan kurang lebih 1 minggu (5 hair) sebelum pelaksanaan pelatihan dimulai. Rizaldy Khair, S.Kom., M.Kom., selaku Narasumber eksternal membawakan materi pelatihan dengan memanfaatkan media zoom meeting. Berdasarkan hasil dari pretest diperoleh bahwa $80 \%$ guru sudah mengetahui dan menggunakan aplikasi zoom meeting, Microsoft Office Power Point dan Microsoft Office Word. Namun belum mengetahui cara memanfaatkan aplikasi Zoom Meeting dan MS. Power Point sebagai media pembelajaran dengan cara membuat video ajar. Selain itu, belum pernah ada media pembelajaran dalam bentuk video interaktif yang disediakan oleh guru TK FARHAN AN-NUR Desa Tumpatan Nibung Kecamatan Batang Kuis-Deli Serdang. Para guru selama ini kesulitan dalam menyampaikan materi jika melaksanakan pembelajaran daring (dalam jaringan) atau online, hal ini karena sangat sulit menyampaikan materi kepada anak TK jika tidak berinteraksi langsung. Oleh karena itu diperlukan kreatifitas dan pengetahuan yang lebih dalam menyusun dan membuat media pembelajaran yang menarik dan dapat dipahami oleh murid/siswa.

Pembuatan media video pembelajaran kali ini membahas bagaimana memanfaatkan aplikasi Zoom Meeting dengan Basic Account. Selamat ini para guru mengetahui bahwa penggunaan zoom meeting dengan full fitur harus berlangganan premium account, akan tetapi mereka baru kali ini mengetahui pemanfaatan basic account bisa melakukan perekaman secara full jika tidak ada user yang bergabung pada room meeting yang kita buka. Setelah mendapatkan pelatihan pembuatan media pembelajaran para guru dapat membuat video pembelajaran sesuai dengan materi yang mereka ampu. Gambar 2 merupakan materi pembuatan media pembelajaran interaktif dengan memanfaatkan aplikasi zoom dengan basic account.

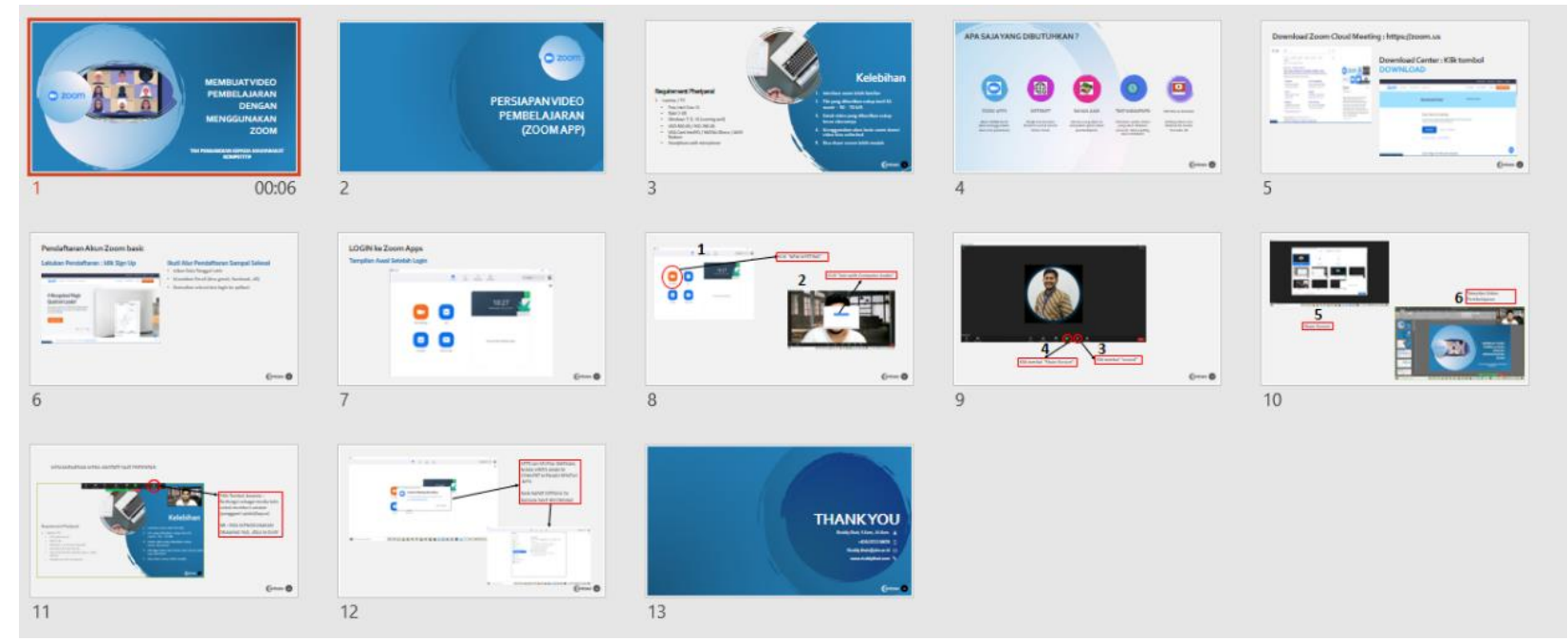

Gambar 2. Materi Pelatihan Pembuatan Media Video Pembelajaran Interaktif dengan Zoom 


\section{Journal of Social Responsibility Projects by Higher Education Forum}

Vol 2, No 2, November 2021, Page 58-61

ISSN 2723-1674 (Media Online)

Setelah diberikan pelatihan pembuatan media pembelajaran berbasis multimedia (video), terjadi peningkatan pengetahuan guru TK Farhan An-Nur tentang penggunaan aplikasi zoom sebagai salah satu media meeting conference bisa membuat video ajar. Gambar 3 menunjukkan suasana pelatihan.
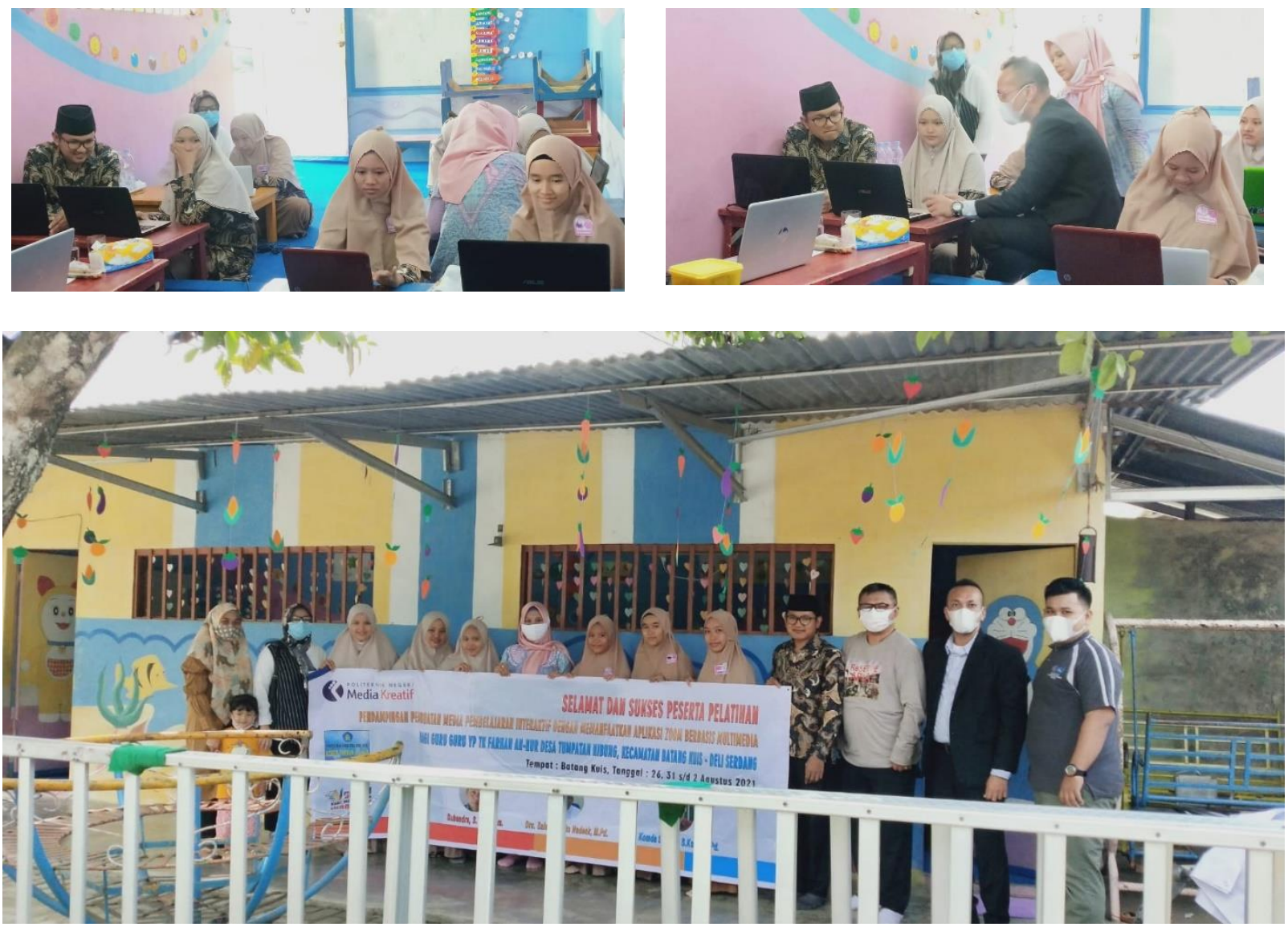

Gambar 3. Suasana Pelatihan

\section{KESIMPULAN}

Program Pengabdian kepada Masyarakat kompetitif ini memberikan feedback positif dari mitra yang merasa sangat puas dan senang atas pelatihan yang dijalankan. Selain itu, mitra berhasil meningkatkan keterampilan dan pengetahuannya. Dan saat ini mitra menjadi kelompok mitra yang lebih kreatif dan inovatif dalam hal membuat bahan ajar dan video pembelajaran sehingga membantu guru dalam hal menyampaikan materi pembelajaran serta murid dan orangtua dalam pembelajaran.

\section{DAFTAR PUSTAKA}

Darmadi, H., 2015. Tugas, Peran, Kompetensi dan Tanggungjawab Menjadi Guru Profesional. Jurnal Edukasi, 13(2), pp. 161174.

Falahudin, I., 2014. Pemanfaatan Media dalam Pembelajaran. Jurnal Lingkar Widyaiswara, 1(4), pp. 104-117.

Putra, S., 2015. Media Pembelajaran Pengenalan Huruf dan Angka di Taman Kanak-Kanak Tunas. Journal Speed-Sentra Penelitian Engineering dan Edukasi, 7(3), p. 24.

Shabir, M. U., 2015. Kedudukan Guru Sebagai Pendidik: (Tugas dan Tanggungjawab, Hak dan Kewajiban dan Kompetensi Guru). Auladuna, 2(2), pp. 221-232.

Tafanao, T., 2018. Peran Media Pembelajaran dalam Meningkatkan Minat Belajar Mahasiswa. Jurnal Komunikasi Pendidikan, 2(2), pp. 104-114.

Tafano, T., 2018. Peran Media Pembelajaran dalam Meningkatkan Minat Belajar Mahasiswa. Jurnal Komunikasi Pendidikan, 2(2), pp. 104-114. 